\title{
Access to intellectual property is a major obstacle to developing transgenic horticultural crops
}

\author{
Gregory D. Graff \\ Brian D. Wright \\ Alan B. Bennett \\ David Zilberman
}

$\nabla$

Inefficiencies in accessing intellectual property (IP) appear to be hindering otherwise valuable research and development (R\&D) in horticultural crop varieties. While leading privatesector agricultural biotechnology firms with strong IP positions and commercial freedom to operate (FTO) see insufficient incentives in the small, fractured markets of horticultural products, researchers with public-sector support for horticultural projects but weak IP positions may find that the best way of gaining FTO and moving forward is to band together and provide mutual access to one another's technologies. The Public Intellectual Property Resource for Agriculture (PIPRA), headquartered at UC Davis, is a new coalition of U.S. universities and foundations committed to this strategy.

tories and rumors have circulated $\checkmark$ for years about biotechnology projects in horticulture being shelved because of intellectual property (IP) conflicts. In a typical situation, a plant scientist at a university agricultural experiment station or a smaller seed firm has developed a remarkable new variety using the cutting-edge scientific tools of plant biotechnology. Then, as they or the nursery or the growers' association with whom they work take the next steps to develop and release the new variety to commercial growers, their efforts are quickly and quietly shut down by a letter from an attorney. The

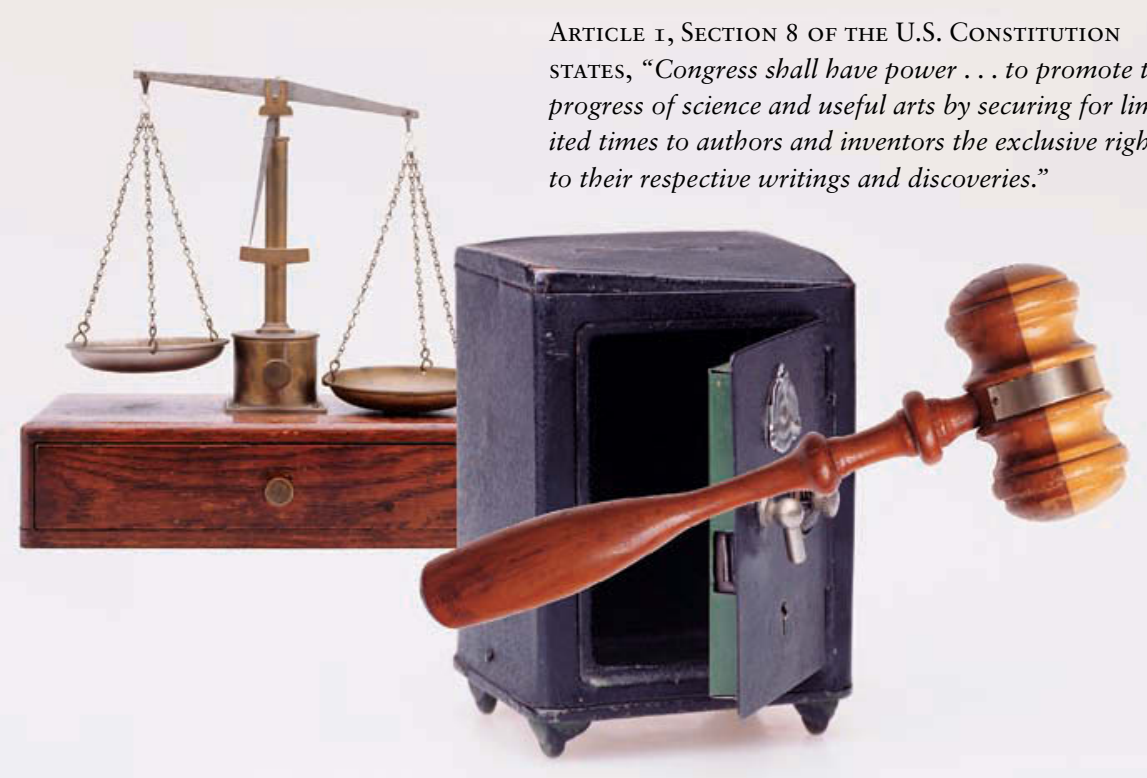

Gathering the legal rights to all the intellectual property necessary for marketing a genetically engineered product can be daunting, especially for smaller companies and public institutions. And the transaction costs to secure "freedom to operate" can be considerable.

letter alleges that the new variety contains a piece of technology that infringes upon a client's IP claims. Furthermore, the patent owner appears not even to be interested in negotiating a license. And to this day, the legendary variety sits in storage somewhere in a greenhouse or a freezer, unused and sadly neglected.

Of course, it is difficult to establish the definitive reasons why a project does not come to fruition, especially when there are numerous factors simultaneously affecting the outcome. Prior patents may be just a convenient excuse - and the patent owners a scapegoat - for tough decisions made to terminate unpromising or economically unattractive projects. Still, while patents do provide convincing incentives for private firms to invest in agricultural research and development (R\&D), taking the necessary steps to respect the rights of patent ownership does add an additional layer of costs for developing new crop varieties. Economists call these additional costs "transaction costs"; they include legal fees for searching and filing patents and expenses for negotiating and drafting licenses. Royalties paid for using another's technology are not IP transaction costs. Rather, they are "rent" paid to use the technology and to compensate for the R\&D expenditures spent to create it.

Commercial developers of agricultural biotechnologies often take measures to avoid incurring these IP transaction costs. They may shift their R\&D strategies or even acquire other companies to avoid dependence on outside technologies, thereby limiting expenses and preventing the complications and uncertainties inherent in "renting" them (Graff, Rausser et al. 2003). These measures, however, can be costly too. Either way, costs faced under an IP system can, in theory, cancel out the private incentives created by IP to pursue innovation. More troubling, IP can even prevent publicly funded innovation from having its intended social impact. Horticultural 
genetics may be one such area of stalled innovation. Yet are there any good indicators of this stalling beyond just stories and rumors? And if so, can we establish links with IP?

\section{Biotech R\&D trends}

Recent U.S. Department of Agriculture (USDA) registrations for field trials of transgenic crops show that $R \& D$ in horticultural crops is lagging when compared with the major row crops. Even leading transgenic horticultural crops such as melon, lettuce, strawberry, grape, apple and sunflower are hardly represented in field trials (fig. $1 \mathrm{~A}$; see page 106). Horticultural crops are completely dwarfed by corn, the single most commonly tested transgenic crop, which by itself is the subject of almost half of all transgenic field trials.

Of course, U.S. production of any single horticultural crop is far less valuable than U.S. production of corn. Less field-testing is to be expected for less valuable crops. But, even when applying a rough calculation to account for the differences in size and value of individual crops - dividing by the annual value of each crop's U.S. production (fig. 1B) - horticultural crops tend to show a greater farm-gate value per field trial. In other words, horticultural crops are subject to fewer genetic field trials, and presumably receive less biotech $R \& D$, for every dollar of crop production.

Furthermore, the proportion of transgenic field trials conducted by publicsector research organizations, such as state universities or the USDA, versus the proportion conducted by commercial firms, varies widely by crop type (fig. 1C). Public-sector involvement in the field-testing of the 10 leading transgenic crops - mostly major row crops - averages just 15\%. Yet, in the next 20 mostly horticultural transgenic crops, public-sector involvement averages much higher, around $40 \%$.

These numbers should be interpreted cautiously, as the samples representing many of the horticultural crops are small and the ratios are taken over just a few field trials. For example, 16 field trials have been done on trans-genic papaya (all by public research organizations) and only 11 on
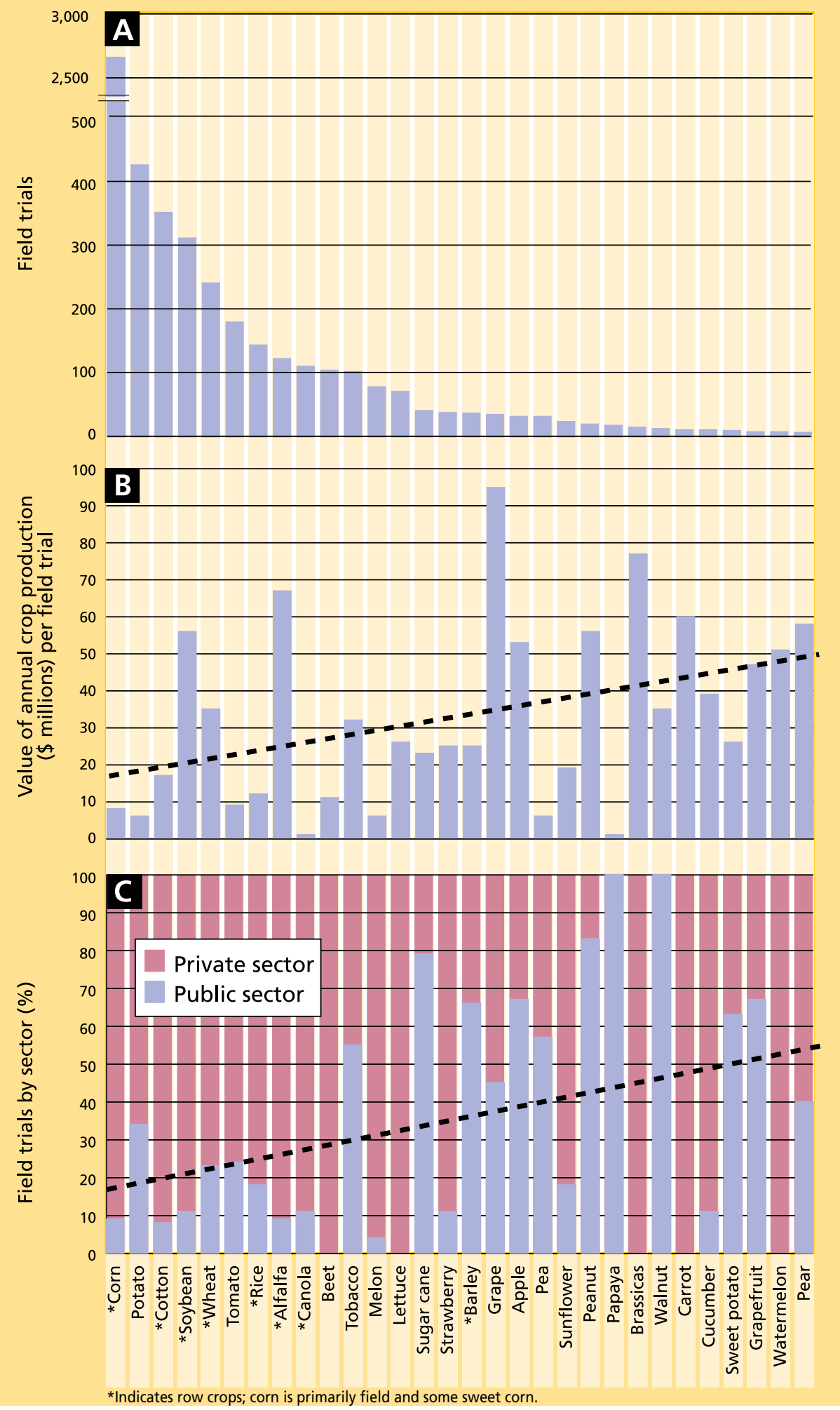

Fig. 1. (A) Top 30 transgenic crops, ranked by total number of field trials registered at USDAAPHIS from June 1997 to May 2002; (B) value of U.S. crop production in 1997 divided by the number of U.S. field trials of the top 30 transgenic crops; (C) percentage of U.S. field trials of top 30 transgenic crops that were conducted by public-sector agricultural R\&D organizations. In figures 1B and 1C, the dotted lines draw simple linear comparisons across crops, ranked according to total transgenic field trials, in order to illustrate questions about broad categorical differences in R\&D investment for different crops; as such, they do not represent statistically tested trends or relationships. 

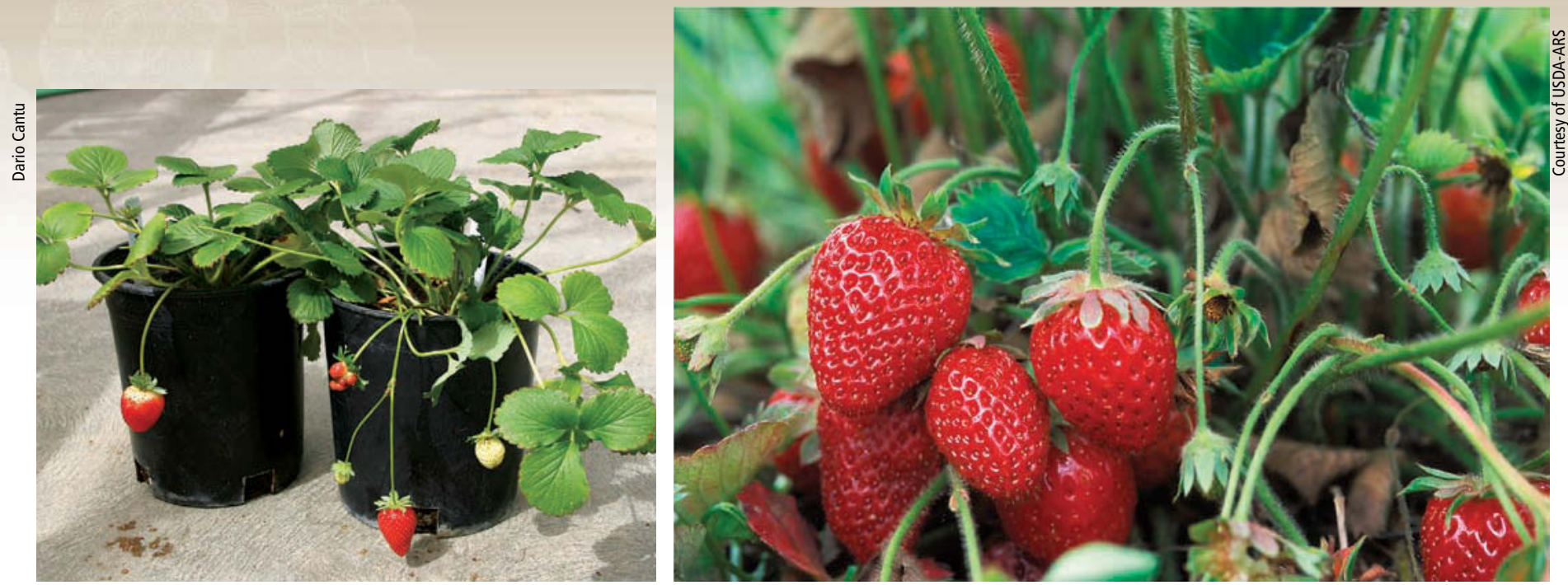

With grant support from the California Strawberry Commission (CSC), UC scientists genetically engineered the strawberry variety 'Selva' with a pear fruit gene for resistance to fungal pathogens. However, the engineered lines have not been tested because of the CSC's subsequent reluctance to support that effort. Left, young genetically engineered strawberries in the greenhouse. Right, conventional strawberries.

transgenic walnut (10 by UC and one by a USDA lab in California).

Despite this variability, there appears to be less investment in biotech for horticultural crops than for major row crops, both in absolute terms and relative to overall crop values, while a greater proportion of that smaller R\&D investment in horticultural crops comes from the public sector. Involvement by commercial firms in horticultural crops seems to be missing. While this data is too sketchy to conclude outright that commercial firms are underinvesting in horticultural biotechnology, it allows us to ask whether they might be, and if so, why.

After a few early excursions into horticultural crops - most notably by Monsanto, Asgrow and Calgene (both now Monsanto subsidiaries) as well as by Syngenta's predecessors at Zeneca - major agricultural biotechnology firms have virtually shut down their product development in horticultural crops. Long-shelf-life tomatoes, virusresistant squash and insect-resistant potatoes have not taken off as did Bt corn and herbicide-tolerant soybeans. Some of the specialized vegetables seed firms, such as PetoSeed (which became Seminis), and some of the smaller agricultural biotechnology firms that specialized in vegetable crops, such as DNA Plant Technologies (later bought out by Seminis), continued their biotechnology efforts a bit longer. Yet those efforts appear to have all but dried up in recent years.
Instead, fruit and vegetable seed companies with active research and production activities, such as Seminis, Danson, Golden Valley, Harris Moran and others, continue to pursue their product development goals through conventional breeding techniques. One exception is the Scotts Company, which is currently seeking regulatory approval for a biotech product for golf courses, a glyphosate-resistant bentgrass. Indeed, most of the biotech work in horticultural varieties is conducted in university laboratories doing basic plant science. Occasionally, those projects spin out a commercially interesting trait or technology, but university technology-transfer offices have a hard time finding commercial partners among the seed firms, nurseries or growers' associations.

\section{Factors discouraging investment}

As with any investment, there is a degree of risk involved in putting resources into the development of a new transgenic horticultural variety. Future returns are uncertain, and expected returns are weighed against costs incurred to enter the marketplace. Such considerations also apply, more generally, to public-sector investments in research. Although the measures of success may be more in terms of scientific advancements than earned profits, the practical importance of a new discovery is still important. (Consider, for example, the scientific as well as commercial impact of virus-resistant papaya [see page 92]).
Market demand. The size and strength of demand for a new transgenic variety will determine the size of returns on the investment. Market uncertainties for agricultural products are nothing new, due to such factors as disruptive competition in supply, cyclical price fluctuations and changes in consumer demand. However, some food consumers, such as in Europe, are skeptical of foods produced using biotechnology. While a majority of U.S. consumers seem relatively unfazed by the genetic contents of processed bulk commodities such as soybeans and feed corn, consumers could react more strongly to obvious modifications of products in the produce aisle. Yet specific market uncertainties surrounding the use of transgenics could be addressed by the selection of technologies and traits that deliver real tangible benefits to consumers in ways that are perceived as unambiguously safe.

Regulatory approvals. The process of regulatory approvals for GM crops is essential to assure the safety of the technology. The R\&D costs associated with gaining approval are considered up-front or "sunk" investments, and they must be spent to gain access to the market. These costs can be greater if the transgenic crop contains novel proteins or pest-control components, as additional assessments are required.

In major row crops, investments to obtain regulatory approval can be recouped from the small technology 


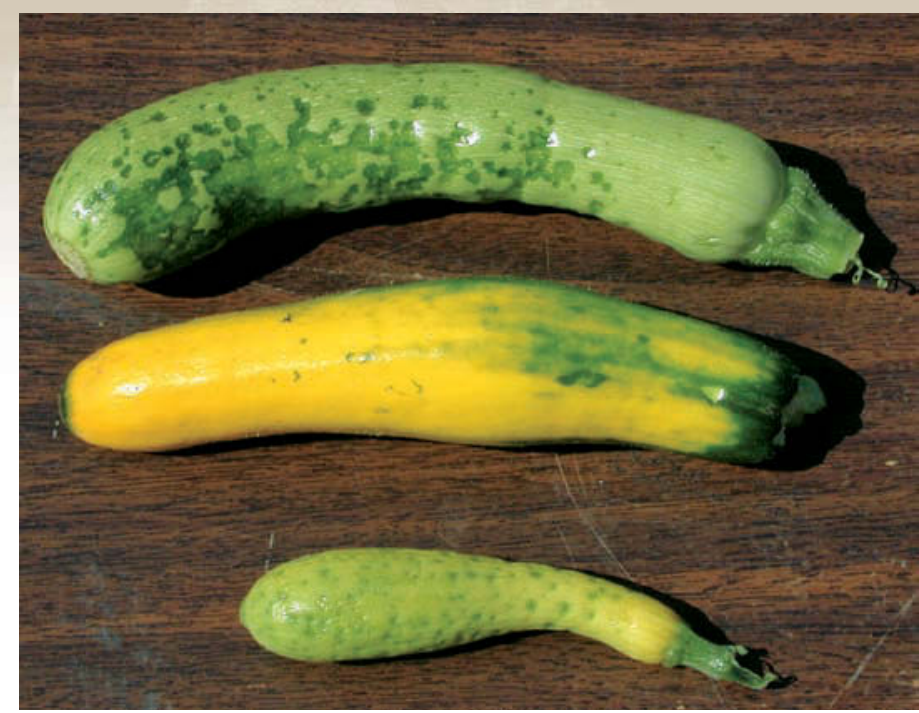

Several different fruits and vegetables have been genetically engineered to resist viral diseases, for which there are often few sources of natural protection. A single gene from the virus itself is inserted into the plant genome, thereby preventing the virus from making

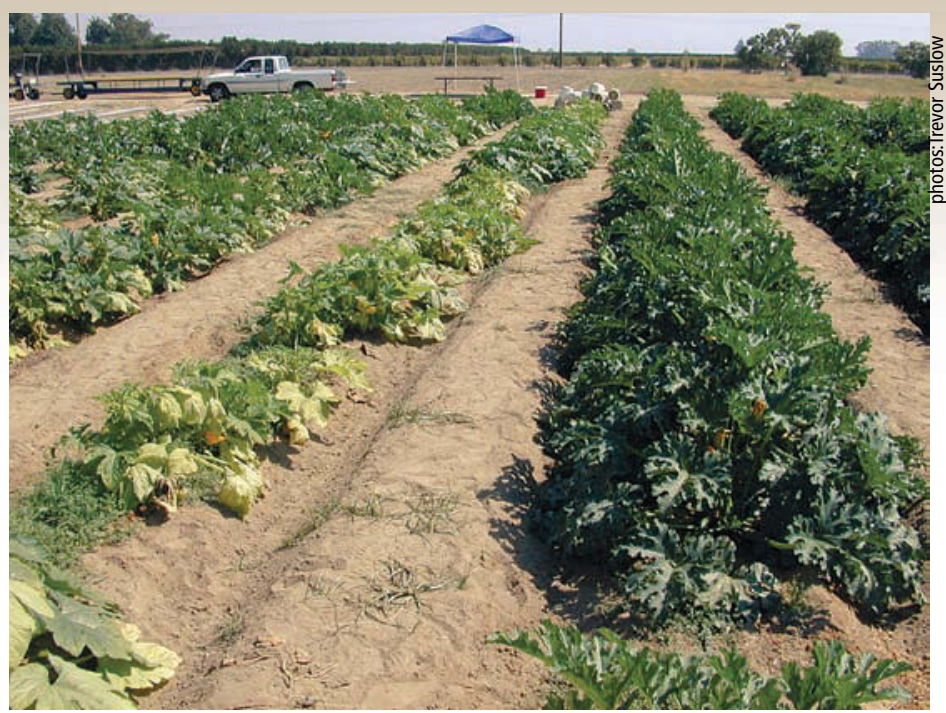

copies of itself and causing disease symptoms, fruit damage and crop losses. Left, yellow zucchini affected by viral diseases. Right, in a field test, genetically engineered zucchini (right) was much hardier than the conventional crop (left). fees charged on each bag of transgenic seed, which are multiplied out over millions of acres planted; however, with horticultural crops the distribution of regulatory costs is often concentrated onto much smaller markets. In many horticultural crops, several different varieties are commercially important. If introgression of the new trait via back-crossing is not an option, such as may be the case for clonally propagated varieties that do not breed true, each variety must be separately transformed in the lab, and each must be separately tested and approved. Regulatory costs would add up, but they could not be spread out over nearly as large a market as could row crops. Still, returns per acre from horticultural varieties tend to be much higher, and the costs of specialized pesticides replaced by transgenic traits may also be higher. In addition, regulatory costs can be expected to decline as more risk assessments are completed, government agencies become more adept at judging the merits of different biotechnologies, and the policies and procedures become streamlined and finely tuned. In addition, the extension of an approach similar to the IR-4 program, which provides regulatory assistance for pesticides targeted to the needs of specialty crops (see page 110), could reduce the regulatory burden on transgenic specialty crops.

\section{Access to intellectual property.}

Transaction costs for gaining freedom to operate (FTO) in the relevant IP- protected technologies can be considerable. As with regulatory costs, the total IP transaction costs are independent of market size, and a larger number of transgenic varieties means more costly negotiations and more deals to cut.

One industry estimate put the costs of negotiating a single crop genetics deal as high as $\$ 100,000$. When multiple patented genetic technologies are stacked in a cultivar, as is increasingly the case, the problem is compounded.

Uncertainty over the total amount of IP transaction costs scares off investment in R\&D projects, unless the expected returns are particularly attractive. This will continue as long as there is uncertainty in the IP landscape for plant biotechnologies and genetic materials. With the number of patents in this area growing at an exponential rate, IP access could be a deterrent to biotech R\&D in horticultural varieties for years to come.

\section{IP hurdles for horticultural crops}

IP access is a general problem for all of crop biotechnology. The reasons lie in the cumulative nature of the genetics and biotechnologies embodied in transgenic varieties. Plants are complex systems, and a healthy, productive crop plant has numerous genetic and metabolic pathways functioning together. Those genetics are inherited from breeding stock or can be added using biotechnology. A genetically engineered seed or plant cultivar may contain three different kinds of technological components that can be protected as IP, including (1) the germplasm of the plant variety, (2) the specific genes that confer a new trait and (3) the fundamental tools of biotechnology such as genetic markers, promoters, and transformation methods. The IP situation is complicated by a number of additional factors that add to the transaction costs.

Complex intellectual-property law. Different technological components of a transgenic crop variety are covered in the United States under different forms of IP law. If a variety is clonally propagated, the germplasm - the plant variety itself - can be claimed as IP at the U.S. Patent and Trademark Office (USPTO) under a Plant Patent, established in 1930 by the Plant Patent Act to protect against cuttings being taken, repropagated and directly resold under another name. Seed-propagated varieties can be claimed as a form of IP under the USDA system of Plant Variety Protection (PVP) certification, established by the Plant Variety Protection Act in 1970. And, since 1980 - following a landmark decision by the Supreme Court in Diamond v. Chakrabarty over the patenting of a genetically engineered microorganism - all kinds of "invented organisms," including novel plant germplasm, have come to be claimed as IP under standard U.S. utility patents. (In practice, plant varieties being claimed by inventors are almost exclusively corn and soybeans, not horticultural varieties.) 


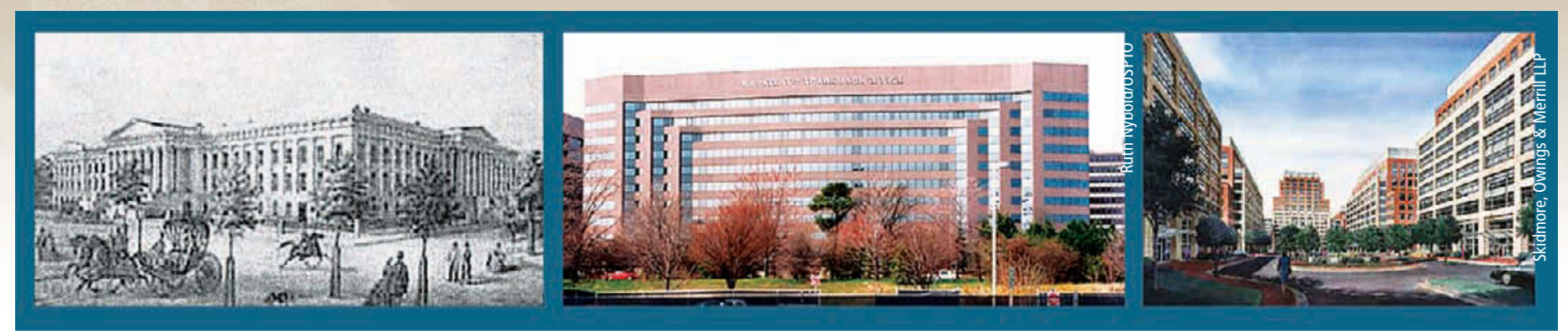

The U.S. Patent and Trademark Office manages intellectual property under the Plant Patent Act of 1930, the Plant Variety Acts of 1970 and 1994, and general utility patents that can cover the products of and processes used to develop genetically engineered seeds and crops. Left to right, U.S. patent office locations past (Washington, D.C.), present (Arlington, Va.) and future (Alexandria, Va.).
Subsequent technological and legal developments following Diamond $v$. Chakrabarty now allow utility patents to protect invented genes, proteins and other gene products, as well as biotechnology tools such as transformation of genetic contents, selection using genetic markers, and regulation of expression using genetic promoters. Finally, a significant part of the value of an agricultural variety often lies not in its technological or biological characteristics per se but rather in its recognition and reputation among consumers in the marketplace. That "brand" name can be protected as IP by registering it as a trademark with the USPTO.

The challenges posed by multiple layers of IP law are, if anything, greater for horticultural varieties than for row crops: plant patents, PVPs or utility patents may cover the germplasm; utility patents typically cover the gene and biotechnology tools used; and trademarks are more often used to protect variety names. In leading row crops such as corn and soybeans, germplasm as well as the genes and biotechnologies are protected more consistently under only utility patents. While trademarks like Roundup Ready or Liberty Link refer to input traits and may be of some value in marketing to farmers, the identities of such agronomic traits command little notice or value from final food consumers.

Exporting to global markets. For many important horticultural crops, exports constitute a large share of output, so FTO under IP must include freedom in foreign markets. Since the various IP rights important for plants are administered nationally, an exporter must check FTO separately in each foreign market. In general, the tools of biotechnology are more likely to be patented in just the major markets - such as the
United States, Europe and Japan - and less likely to be patented in countries with smaller markets. Uses of biotechnologies specifically for minor crops are less likely to be widely patented in multiple countries than are uses in important field crops. However, as a result of the International Union for the Protection of New Varieties of Plants (UPOV) agreement first established in 1961, PVP systems are widely available overseas for the protection of clonally propagated varieties, and such varieties do tend to be widely registered in multiple countries. Still, not all types of biotechnologies, genes or plant germplasm can be protected in all countries. For example, utility patenting of plants is allowed in only a few countries (including the United States).

Beyond these trends, however, there are no hard-and-fast rules as to which technology will be protected in which country, as each inventor decides where to seek protection (Binenbaum et al. 2003). As a result, those seeking FTO are confronted by an often bewildering international patchwork of IP rights, where the negotiations needed for a particular transgenic variety can differ significantly each time it crosses a national border.

Intellectual-property holders. Unless a new transgenic variety is developed by an integrated effort at a large company backed by a broad IP portfolio, a number of different owners - including companies, individuals, universities and even governments - will have valid IP claims over the technologies and genetic contents that end up being included in it. That means there are numerous owners to track down, negotiations to conduct, billable legal time to hire, and multiple royalty payments to administer. The costs and headaches involved in working out "who owns what" and "who owes what to whom" can balloon into what economists call the "tragedy of the anti-commons" and render the development process unfeasible. The "tragedy" is arguably worse in horticultural crops than in row crops. Given the smaller markets involved, there is less incentive in industry to consolidate IP portfolios around horticultural crops. Also, not one of the public-sector organizations or their typically smaller commercial partners in horticultural crop development has a complete IP portfolio in plant biotechnology.

\section{Uncertain ownership of rights.}

When technologies are patented, it is often not clear who currently owns particular aspects of each technology. This uncertainty is cleared up in the courts through patent interference cases, where attorneys and scientists undertake intensive "surveying" of the "property lines" between the patents and technologies in question. Sometimes these cases drag on for years, keeping key technologies in legal limbo and the R\&D community guessing as to who is the rightful owner. Yet, for most registered patents there is no such scrutiny. As a result, the boundaries for a considerable expanse of technological territory are not clearly demarcated, creating considerable uncertainty as to when a new application could be considered to be infringing or "trespassing." In horticultural crops, the lack of clarity about the scope and validity of patent claims is especially important. Because the markets are smaller, fewer products have been developed and fewer contests have been fought to establish legal precedents. Furthermore, just the anticipation of possible legal costs can shut a project down before it ever gets off the ground. 
New biotech crops must meet the intellectual-property and regulatory requirements of importing countries, and there are no firm rules as to which technologies will be protected or regulated in which countries. This situation can create serious difficulties for exporters. Right, food market in Benin; far right, Ethiopia.

Transfer of rights. IP covering a crop variety may be sold, licensed or transferred to another organization at any time. The transfer of rights can occur either in part (nonexclusively) or in whole (exclusively). The transfer can happen in just one territory where it is protected (such as the United States) or in multiple territories. The transfer of rights for a biotechnology tool or gene could be specified for use in just one crop (such as corn), in several crops (such as all cereal grains), or in any and all crops. Finally, to make matters worse, the fact that the IP rights have been transferred may be considered commercially sensitive information and not be made public.

Other issues. Any organization managing the release of a new crop variety faces uncertainty about which IP rights actually cover what technologies, who holds those rights in which countries, and to what degree a specific new transgenic variety infringes on those rights. Resolution of such uncertainty is not less costly for crops with small market value. Even after reliable information is obtained, uncertainty remains about negotiating the permissions. IP owners are not required to negotiate licenses, and they may feel there is not enough potential revenue in minor crops to make their licensing efforts worthwhile. They may also be concerned about technology stewardship, given the nervousness among consumers about food biotechnology and its status as a hot media topic. They may worry that the mishandling of their technology by a small and relatively inexperienced horticultural player could lead to stronger regulations, potentially eroding that technology's value in its major crops, or jeopardize public perceptions about biotechnology overall.
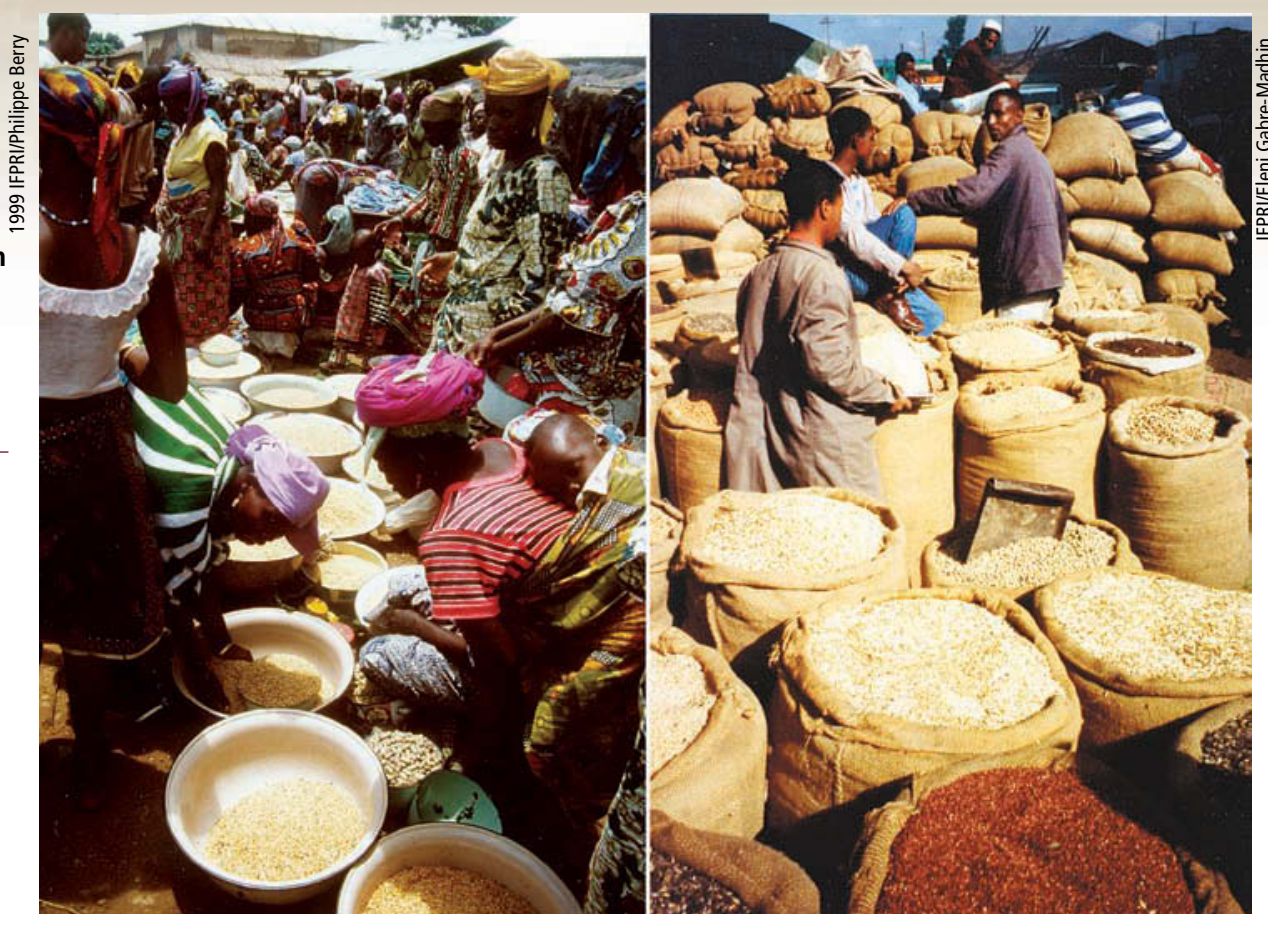

\section{Public-sector IP management}

In response to IP congestion and continuing uncertainties, several leading U.S. public-sector agricultural research organizations have come together to create the Public Intellectual Property Resource for Agriculture (PIPRA), an organization providing collaborative IP management solutions to public-sector and smaller private-sector players in horticulture (Atkinson et al. 2003; see sidebar, page 127). While individual universities and even the USDA have small and uncoordinated IP portfolios in plant genetics, together they hold a fairly comprehensive set of technologies that could be useful for developing transgenic varieties (Graff, Cullen et al. 2003). PIPRA seeks to coordinate the disparate portfolios of its member organizations to support specialty crop applications. With the offices of technology transfer of its member organizations, PIPRA is pursuing several cooperative strategies.

Licensing terms. First, PIPRA seeks to develop and adopt more precisely focused terms of licensing, with specific distinctions for the "fields of use" to which a technology is licensed. A company that licenses a technology invented at a university can still get the full benefit of using the technology in those major row crops in their line of business, even if the license clearly defines and grants exclusive use of the technology in just those crops. Such a license effectively "reserves" the rights to use the technology in any other crops. Horticultural firms could then make separate agreements with the university to use the technology in only their defined specialty crops. An advantage of this strategy is that it can also apply to other minor uses, such as "alternative" crops (such as cassava or millet) or humanitarian applications in staple crops for developing countries (such as vitamin A-fortified Golden Rice). By discriminating between big markets and multiple smaller markets - including those with limited commercial value but important social benefits - publicsector scientists could see their inventions earn royalties in the big markets of major row crops while still helping to improve smaller crops or increase food security in world's poorest regions.

PIPRA database. A database will, for the first time, list in one place current information about all of the patents of PIPRA's members and their availability for licensing alongside information about technologies published in the scientific literature (and thus publicly available), in sufficient detail to identify which technologies can be accessed for which uses. The database will offer 
a clear, complete and certain "universal listing" of technologies available from PIPRA's member organizations and the public domain.

Commercial patent databases and professional legal staff are available to researchers in large private companies to search through the "prior art" (the records of what is already patented) to make FTO analyses of a new product's IP position. Such resources are seldom available to academic and government researchers. The PIPRA database will decrease uncertainty about what cannot be used by showing what can be used.

Patent-pooling. PIPRA is investigating the creation of patent-pooling mechanisms, which would collect IP submitted from its member organizations, package the technologies together and offer unified licenses for the "bundled" IP in a field of use, such as a specific crop, or in a particular state or country. This process mimics, in a virtual way, how large commercial firms have assembled their IP portfolios to provide FTO in major field crops. Its feasibility will depend - at least at the outset - on the extent to which public-sector organizations are able and willing to provide access to patents covering key enabling biotechnology tools already licensed to the corporate sector.

Even if used to access technologies on just a patent-by-patent basis, coordinated information and streamlined access to academic and governmentowned IP could help decrease transaction costs and improve efficiency in technology-transfer markets. There is ample room for improvement here, as some have complained that negotiating licenses from universities and government agencies is often less efficient than negotiating licenses from firms. PIPRA can improve public-sector technology transfer for agriculture by providing information, tools, and precedents for efficient licensing.

Greater opportunities lie in the steps being taken to coordinate access, package IP bundles, and target uses

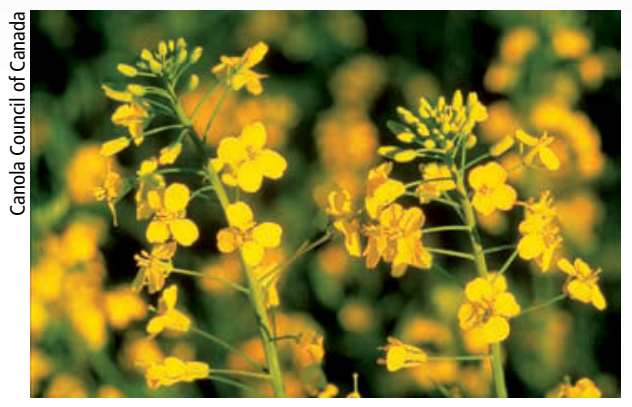

Right, the orange canola seeds have been genetically engineered to produce high levels of beta-carotene. Monsanto has licensed the technology and is working with the Tata Energy Research Institute in India and Michigan State University's Agricultural Biotechnology Support Program to develop high beta-carotene mustard for possible use in India. Above, a conventional canola plant.

in lower-value markets such as horticultural crops and traits important for food security in developing countries. These are, generally speaking, areas in which commercial firms are not interested or capable of serving. Such collaboration is not surprising, given the history and ethos of cooperation among agricultural experiment stations within the land-grant system. Public-sector institutions also have greater legal flexibility to enter into collective IP management arrangements, given historical antitrust concerns about abuses of patent-coordination efforts in industry.

Even more important will be the establishment of ongoing precedents and mechanisms for the treatment of future IP. Academic and government researchers will go on making important discoveries and inventing new technologies for agriculture. Those future inventions will, from their inception, be handled in ways - such as being listed in the universal database, licensed for targeted "fields of use" and included in IP-pools - that will make them accessible in a carefully proscribed manner, not just to top commercial bidders, but to anyone else in the broader agricultural community who can make good use of the

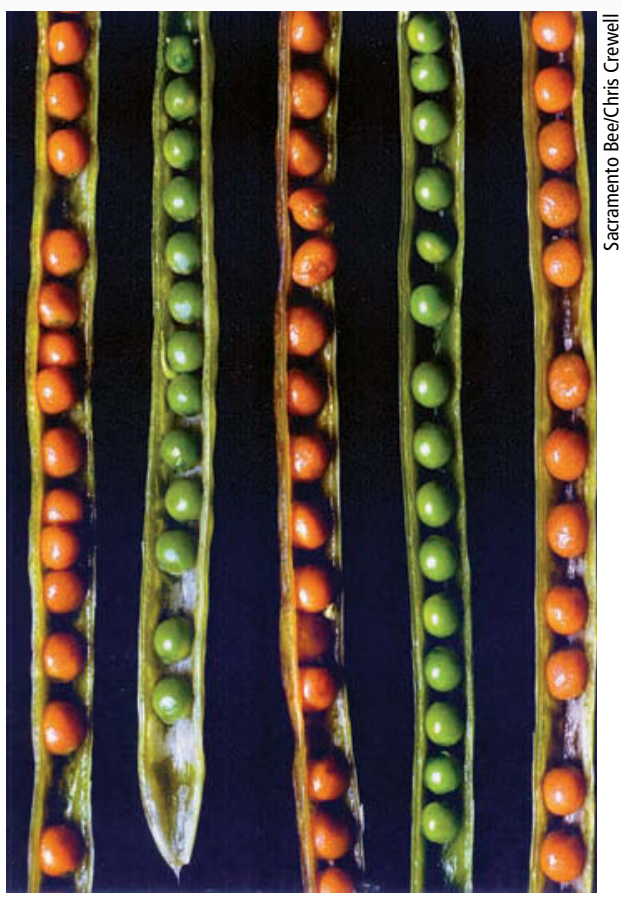

technology, including horticultural researchers and growers.

G.D. Graff is Researcher, B.D. Wright is Professor, and D. Zilberman is Professor, Department of Agricultural and Resource Economics, UC Berkeley; and A.B. Bennett is Professor, Department of Vegetable Crop Science, UC Davis, and Executive Director, Office of Technology Transfer, UC Office of the President. Wright and Zilberman are members, Giannini Foundation.

\section{References}

Atkinson RC, Beachy RN, Conway G, et al. 2003. Public sector collaboration for agricultural IP management. Science 301:174-5.

Binenbaum E, Nottenburg C, Pardey PG, et al. 2003. South-North trade, intellectual property jurisdictions and freedom to operate in agricultural research on staple crops. Ec Dev Cultural Change 51:309-35.

Graff GD, Cullen SE, Bradford KJ, et al. 2003. The public-private structure of intellectual property ownership in agricultural biotechnology. Nature Biotech 21:989-95.

Graff GD, Rausser GC, Small AA. 2003. Agricultural biotechnology's complementary intellectual assets. Review Econ Statistics 85:349-63. 